Jayalath, C. and Perera, B.A.K.S., 2019. Policy gaps that deter fostering sustainable construction in Sri Lanka. In: Sandanayake, Y.G., Gunatilake, S. and Waidyasekara, A. (eds). Proceedings of the $8^{\text {th }}$ World Construction Symposium, Colombo, Sri Lanka, 8-10 November 2019, pp. 484-492. DOI: doi.org/10.31705/WCS.2019.48. Available at: https://2019.ciobwcs.com/papers

\title{
POLICY GAPS THAT DETER FOSTERING SUSTAINABLE CONSTRUCTION IN SRI LANKA
}

\author{
Chandana Jayalath ${ }^{1}$ and B.A.K.S. Perera ${ }^{2}$
}

\begin{abstract}
One of the guiding principles used for structuring the policy of construction in Sri Lanka is to ensure achieving sustainable development. Though the construction practitioners in Sri Lanka are aware of sustainable construction practices, there is lack of verification as to enthusiasm of the state policy that has been extended to this noble cause. A desk review was carried out to demystify the existing policy directions. A comprehensive literature survey was carried out to identify the drivers and barriers of its implementation. A structured questionnaire survey was conducted among 100 individual practitioners to gauge their perception and experience. 80 responses were received, 62 were considered valid for analysis. Data collected were then analyzed using the relative importance index. It was revealed that the key driver is end user requirements and the crucial barrier is lack of policies. Only 3 out of 17 dimensions have been at least superficially earmarked within the policy framework. The study suggests that the uptake of enhanced policies would indeed help in fostering sustainability. The outcome will be valuable for the government officials to formulate a policy that truly promotes strategic direction. This is the first local research on identifying policy gaps related to the subject arena.
\end{abstract}

Keywords: Barriers; Drivers; Policy Making; Sri Lanka; Sustainability.

\section{INTRODUCTION}

In Sri Lanka, the guiding principles in structuring the policy of construction industry are to include combating environmental impacts and achieving sustainable development. The National Policy for Construction is formulated in terms of the provisions of Subsection 2 (1) of the Construction Industry Development Act No.33 of 2014. As stated, the aim of the construction policy is to create an efficient construction industry through regulation, standardization, capacity building and facilitation. A policy is deemed to be contextual and substantive. Context is all about barriers and drivers that affect the implementation of practices. Hence it is considered imperative to find out any policy dimensional gaps that eventually deter the sustainable practices and to highlight some promising ideas which could successfully fill those gaps. First, different definitions of sustainability are presented, and these aspirational standards are tested empirically as to their importance and compared with current policy goals. This is indeed a precursor to any policy revisit after 5 years of its introduction.

\footnotetext{
${ }^{1}$ Department of Quantity Surveying, University of Vocational Technology, Sri Lanka, chandanaj@univotec.ac.lk

${ }^{2}$ Department of Building Economics, University of Moratuwa, Sri Lanka, kanchana@uom.lk
} 
The aim of this research is therefore to gauge the enthusiasm of the construction policy extended to the noble cause of sustainable construction. The objectives are to identify drivers, barriers, and policy gaps of sustainable construction.

\section{DEMYSTIFYING SUSTAINABLE CONSTRUCTION}

According to DuBose et al. (1997), "sustainability reconciles the pervasive human desire for a high quality of life with the realities of the global context. It calls for unique solutions for improving welfare that do not come at the cost of degrading the environment or impinging on the wellbeing of other people". Sustainable development was defined by the World Commission on Environment and Development (1987) as the development that meets the needs of the present without compromising the ability of future generations to meet their own needs. Hill and Bowen (1987) identified four attributes of sustainability; social, economic, biophysical and technical. These are supplemented with a set of overarching, process-oriented principles. Kibert (1994) finds sustainable construction as creating a healthy built environment using resource-efficient, ecologically based principles. According to Lawson (1992), sustainable construction includes 'cradle to grave' appraisal. Professional actors in the construction industry construct definitions of sustainable development to valorize their professional role (Abrahams, 2017). All stakeholders at all stages should commit to sustainability to enable change in perception to start with (Sfakianaki, 2015). The key factors that need to be considered include the release of conceptual guidelines and management regulations (Shi et al., 2012). This warrants a careful study on the drivers and barriers at the outset. Drivers are meant to be the various elements that trigger, sustain and expand the uptake of sustainable construction practices. On the other hand, "barriers" are the conditions that impede progress towards achieving a strategic business objective (Vandierendonck et al., 2010). However, there is ample requirement to apply these concepts in the local construction projects (Karunasena et al., 2016).

In a nutshell, sustainable development is a complex composite policy goal (Rydin et al., 2007). The way of positioning the construction sector into the global approach of sustainable development should be clarified and clearly claimed (Bourdeau, 1999). However, more holistic approaches are quite absent (Heijden and Bueren, 2013). A factor that may be hindering is the 'convoluted' nature of the policies (Warnock, 2007). Any national policy has to address this complex matrix. A policy offers a framework which is certainly useful for benchmarking. A policy provides a generic structure allowing flexibility (Presley and Meade, 2010). However, much of the research on technical and scientific knowledge has focused on the emergence of policy agendas (Rydin et al., 2007). The gap between policy intent and effective solutions remains difficult to close (Meacham, 2016). For effective policymaking, it is essential that these various paths (dimensions) be disentangled so that the policies may be targeted in a manner that induces a changed behaviour away from environmentally damaging inequitable growth (Robert and Herman, 1996).

\section{DRIVERS AND BARRIERS}

There are a number of challenges in introducing sustainable practices and certain enablers need adopting a more sustainable path (Plessis, 2007). Tables 1 and 2 depict the drivers and barriers of sustainable construction identified by past researchers, respectively. 
Table 1: Drivers identified by past researchers

\begin{tabular}{ll}
\hline \multicolumn{1}{c}{ Drivers } & \multicolumn{1}{c}{ Reference } \\
\hline $\begin{array}{l}\text { Policy imposition } \\
\text { Client requirements }\end{array}$ & Opoku and Ahmed (2014) \\
\hline Green reputation & Abrahams (2017) \\
Stakeholder influence & \\
Competitive advantage & \\
Legal requirement & Roper and Beard (2006) \\
\hline Concession of tax & \\
Awareness on impacts & Bash and Haikines (2015) \\
\hline $\begin{array}{l}\text { Monitoring system in place } \\
\text { Certification program }\end{array}$ & \\
Accreditation scheme & \\
Regular audits & \\
\hline Customer willingness to pay extra for green initiatives & Presley and Meade (2010) \\
\hline Societal accountability & Majdalani et al. (2006) \\
Specific tender weightage on sustainable elements & \\
Technical knowhow & \\
\hline Improved process flow and productivity & Rydin et al. (2007) \\
\hline Improvement in environmental quality & Ogunbiyi et al. (2014) \\
\hline Integration of principles of lean construction & Mohamed et al. (2017) \\
$\begin{array}{l}\text { Energy conservation } \\
\text { Improving indoor environmental quality }\end{array}$ & Meacham (2016) \\
Environmental/resource conservation & Ahn et al. (2013) \\
Waste reduction & \\
\hline
\end{tabular}

Table 2: Barriers identified by past researchers

\begin{tabular}{ll}
\hline \multicolumn{1}{c}{ Barriers } & \multicolumn{1}{c}{ Reference } \\
\hline $\begin{array}{l}\text { Lack of policy } \\
\text { Lack of design itself }\end{array}$ & Opoku and Ahmed (2014) \\
Lack of codes & Arif et al. (2013) \\
\hline $\begin{array}{l}\text { Lack of public awareness } \\
\text { Lack of demand }\end{array}$ & \\
Lack of strategic direction & Ahn et al. (2013) \\
\hline $\begin{array}{l}\text { Low level of education and experience on sustainable } \\
\text { construction }\end{array}$ & \\
$\begin{array}{l}\text { Lack of demand for sustainable buildings } \\
\text { Tendency to maintain current practices, and limited } \\
\text { knowledge and skills of subcontractors }\end{array}$ \\
\hline Wrong perceptions on capital costs & Susan and Eric (2014) \\
\hline $\begin{array}{l}\text { Lack of expertise } \\
\text { Lack of database } \\
\text { Resistance to change }\end{array}$ & Ahn et al. (2013) \\
\hline
\end{tabular}




\begin{tabular}{ll}
\hline \multicolumn{1}{c}{ Barriers } & Reference \\
\hline Lack of government support & \\
Lack of measurement tools & \\
Lack of incentives & \\
Lack of audits & \\
Higher investment costs & \\
Lack of cooperation & \\
Lack of technology & Wyatt et al. (2000) \\
Lack of training & Athapaththu and \\
Increased capital costs & Karunasena (2018) \\
\hline Learning curve & \\
Attitudinal issues & \\
Lack of priority & \\
Lack of life cycle initiative & \\
More complex planning & \\
Building control systems & \\
Gaps in the legal framework & \\
Weak enforcement of prevailing rules & \\
Less institutional intervention & \\
Less commitment of key stakeholders &
\end{tabular}

\section{RESEARCH METHODOLOGY}

This study used a mixed approach where the validity and reliability of results are enhanced (Lund, 2012; Neuman, 2011). As the first step of the process, a desk review was carried out on the existing policy of construction in Sri Lanka to identify policy gaps if any. A literature survey was undertaken to identify drivers and barriers. An interview guideline was developed with the use of literature findings. A questionnaire was subsequently piloted on five (5) senior construction practitioners those who have more than 25 years working experience to establish the appropriateness of the questions and alleviate the inconsistencies if any. Some of the questions were amended to reflect the views of the pre-test respondents. A structured questionnaire involving closed-ended queries was subsequently disseminated among 100 construction practitioners in Sri Lanka using a stratified sampling method via online Google forms survey and 62 completed questionnaires were received with the rate of response of $62 \%$ (Table 3 ). The respondents were required to rank the extent to which each of the barriers and drivers do exist using a 5 -point Likert scale. The degree of perception was taken on the Likert scale of $5=$ strongly agree, $4=$ agree, $3=$ fairly agree (average), $2=$ disagree, $1=$ strongly disagree. RII (refer equation 01) was used for the analysis. RII aids in finding the contribution a particular variable makes to the prediction of a criterion variable both by itself and in combination with other predictor variables Johnson and LeBreton (2004). RII was calculated using equation (01).

$$
R I I=\frac{\Sigma W}{A \times N}
$$

Where: RII= Relative Importance Index; W= Weighting given to each factor by the respondents, $\mathrm{A}=$ Highest weight and $\mathrm{N}=$ Total number of respondents. 
Table 3: Profile of the respondents

\begin{tabular}{|c|c|c|c|c|c|c|c|c|}
\hline \multirow[b]{3}{*}{$\begin{array}{l}\text { Designation of } \\
\text { Respondents }\end{array}$} & \multicolumn{8}{|c|}{ Years of Experience } \\
\hline & \multicolumn{2}{|c|}{10 to 15} & \multicolumn{2}{|c|}{15 to 20} & \multicolumn{2}{|c|}{20 to 25} & \multicolumn{2}{|c|}{ More than 25} \\
\hline & 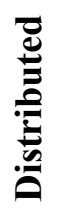 & 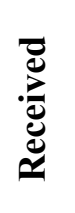 & 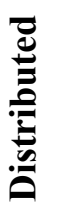 & 苋 & 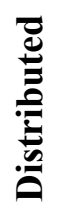 & 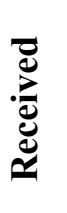 & 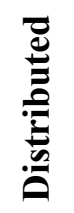 & 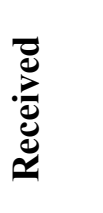 \\
\hline Construction Manager & 5 & 4 & 5 & 3 & 5 & 4 & 5 & 3 \\
\hline Site Manager & 5 & 3 & 5 & 2 & 5 & 2 & 5 & 2 \\
\hline Project Manger & 5 & 4 & 5 & 4 & 5 & 4 & 5 & 3 \\
\hline General Manager & 5 & 2 & 5 & 2 & 5 & 3 & 5 & 3 \\
\hline $\begin{array}{l}\text { Training experts in } \\
\text { Construction Sector }\end{array}$ & 5 & 3 & 5 & 4 & 5 & 4 & 5 & 3 \\
\hline Total Responses & 25 & 16 & 25 & 15 & 25 & 17 & 25 & 14 \\
\hline Rate of Response & & & & & & & & \\
\hline
\end{tabular}

Findings of the empirical study were mapped with the literature findings and overlap factors were identified as 'crucial' in policy considerations.

\section{FINDINGS AND DISCUSSION}

\subsection{Policy REVIEW}

A desk review was carried out to identify the policy actions and derivatives falling within the purview of sustainable construction. As such, the National Policy for Construction was formulated in terms of the provisions of Subsection 2 (1) of the Construction Industry Development Act No.33 of 2014. It was found that there are three key policy priorities namely, energy efficiency, disaster resilience and environment friendliness. Though the policy is silent on application on traditional knowledge, it must be noted that, the Construction Industry Development Act (CIDA), No. 33 of 2014 stipulates that in formulating the National Policy, emphasis shall be given to the involvement of professionals within the construction industry, including resource personnel in the field of traditional knowledge. The policy gaps are those silent in the various existing regulations (where the directives are not given as shown in Table 5). It does not broadly address any implementation mechanism either.

\subsection{EMPIRICAL STUDY}

A total of 80 responses were received and 62 were deemed to be valid for analysis after data screening, thus representing $62 \%$ response rate. $33 \%$ had never been engaged in sustainable construction projects. $45 \%$ reported that 1 out of 10 projects uses sustainable construction concepts whilst $22 \%$ reported that 1 out of 25 projects uses sustainable construction methods. Again, the majority had engaged in less than five such projects. It is observed that sustainable construction practices are not frequent. There are 10 key drivers and 14 barriers found in the empirical study. Tables 4 and 5 depict their overlap with the literature findings which indicates that these overlap factors are more imperative than non-overlap factors in drafting a policy. 
Table 4: Empirical ranking of drivers and their overlap $(O / L)$ with literature findings

\begin{tabular}{lccc}
\hline \multicolumn{1}{c}{ Drivers } & RII & O/L & Rank \\
\hline Client requirements & 0.79 & $\mathrm{X}$ & $1^{\text {st }}$ \\
Stakeholders' influence & 0.71 & $\mathrm{X}$ & $2^{\text {nd }}$ \\
Cost efficiency & 0.69 & & $3^{\text {rd }}$ \\
Competitive advantage & 0.68 & $\mathrm{X}$ & $4^{\text {th }}$ \\
Legislative provisions & 0.67 & $\mathrm{X}$ & $5^{\text {th }}$ \\
Awareness & 0.67 & $\mathrm{X}$ & $5^{\text {th }}$ \\
Clear and consistent guidelines & 0.65 & $\mathrm{X}$ & $7^{\text {th }}$ \\
Win more contracts to remain in business & 0.64 & & $8^{\text {th }}$ \\
Financial incentives & 0.60 & $\mathrm{X}$ & $9^{\text {th }}$ \\
Company reputation and brand image & 0.59 & & $10^{\text {th }}$ \\
\hline
\end{tabular}

Table 5: Empirical ranking of barriers and their overlap $(\mathrm{O} / \mathrm{L})$ with literature findings

\begin{tabular}{lccc}
\hline \multicolumn{1}{c}{ Barriers } & RII & O/L & Rank \\
\hline Lack of polices & 0.76 & $\mathrm{X}$ & $1^{\text {st }}$ \\
Lack of codes & 0.72 & $\mathrm{X}$ & $2^{\text {nd }}$ \\
Lack of financial incentives & 0.69 & $\mathrm{X}$ & $3^{\text {rd }}$ \\
Lack of investment & 0.68 & $\mathrm{X}$ & $4^{\text {th }}$ \\
Initial cost & 0.67 & $\mathrm{X}$ & $5^{\text {th }}$ \\
Lack of client demand & 0.66 & $\mathrm{X}$ & $6^{\text {th }}$ \\
High cost of environmental service & 0.66 & $\mathrm{X}$ & $6^{\text {th }}$ \\
Insufficient research & 0.64 & $\mathrm{X}$ & $8^{\text {th }}$ \\
Lack of public awareness & 0.64 & $\mathrm{X}$ & $8^{\text {th }}$ \\
Competitive pressure & 0.62 & $\mathrm{X}$ & $10^{\text {th }}$ \\
Lack of database & 0.62 & & $10^{\text {th }}$ \\
Lack of green products & 0.60 & $\mathrm{X}$ & $12^{\text {th }}$ \\
Lack of expertise & 0.58 & & $13^{\text {th }}$ \\
\hline
\end{tabular}

With regard to barriers that inhibit the sustainable practices, respondents were asked to rank 14 items on a scale of 1 to 5 with one being the least significant factor and five being the most favoured factor. The analysis revealed that "lack of policies" was the first barrier. The lack of building codes was the next in line. It recorded a value of 0.72 . This is followed by lack of investment with a value of 0.69 . The least rank RII was the lack of lack of expertise. Further, the empirical ranking of drivers and barriers and their overlap with the literature findings highlight the priority of policy wise attention. Overlap is where the factors emphasized in both literature survey and empirical study.

Having identified that the lack of policies is the topmost barrier (Table 4), respondents were next asked to rank the various dimensions of sustainable construction drivers found in the empirical study. The most ranked dimension was "traditional knowledge". It recorded an RII value of 0.84 . This was followed by "environmental friendliness" with an RII value of 0.81 . Priority of projects was ranked again second with an RII value 0.81 . The least ranked dimension was 'valuation of bonus' with an RII of 0.60 . There are 17 
dimensions ranked in the order of their relative importance so that the policy gaps with no directives become apparently plausible. The findings are illustrated in the Table 6 .

Table 6: Ranking of policy dimensions

\begin{tabular}{|c|c|c|c|c|}
\hline Dimension & Policy Profile & RII & Rank & Policy Directives \\
\hline $\begin{array}{l}\text { Traditional } \\
\text { Knowledge }\end{array}$ & Foster culture in adapting TK & 0.84 & $1^{\text {st }}$ & $\begin{array}{l}\text { CIDA Act, No. } \\
33 \text { of } 2014, \\
\text { Article } 2 \text {, Part } 1\end{array}$ \\
\hline $\begin{array}{l}\text { Environmental } \\
\text { friendliness }\end{array}$ & $\begin{array}{l}\text { Stimulate adoption of } \\
\text { environmentally favourable } \\
\text { construction practices }\end{array}$ & 0.81 & $2^{\text {nd }}$ & $\begin{array}{l}\text { National } \\
\text { Construction } \\
\text { Policy, Sec 2.2, } \\
\text { VI }\end{array}$ \\
\hline $\begin{array}{l}\text { Priority of } \\
\text { projects }\end{array}$ & $\begin{array}{l}\text { Take a scientific and apolitical } \\
\text { approach }\end{array}$ & 0.81 & $2^{\text {nd }}$ & \\
\hline $\begin{array}{l}\text { Building } \\
\text { adaptive reuse }\end{array}$ & $\begin{array}{l}\text { Espouse means of BAR in respect of } \\
\text { buildings nearing obsolesce }\end{array}$ & 0.81 & $2^{\text {nd }}$ & \\
\hline Research & $\begin{array}{l}\text { Establish centrally coordinated arm } \\
\text { of research }\end{array}$ & 0.76 & $5^{\text {th }}$ & \\
\hline Land use & $\begin{array}{l}\text { Use non-arigable lands and } \\
\text { harmonize land policy ensure } \\
\text { complementarity }\end{array}$ & 0.74 & $6^{\text {th }}$ & \\
\hline $\begin{array}{l}\text { Low carbon } \\
\text { initiatives }\end{array}$ & $\begin{array}{l}\text { Encourage supply chain in carbon } \\
\text { free materials and process selection }\end{array}$ & 0.72 & $7^{\text {th }}$ & \\
\hline $\begin{array}{l}\text { Deconstruction } \\
\text { and recycling }\end{array}$ & $\begin{array}{l}\text { Minimize the release of building } \\
\text { debris to the environment }\end{array}$ & 0.71 & $8^{\text {th }}$ & \\
\hline \multirow[t]{2}{*}{ Solar energy } & Explore market potentials & 0.71 & $8^{\text {th }}$ & \\
\hline & Grant concessions & 0.70 & $10^{\text {th }}$ & \\
\hline $\begin{array}{l}\text { Green } \\
\text { technology }\end{array}$ & $\begin{array}{l}\text { Promote green in all design, } \\
\text { construction and maintenance } \\
\text { aspects }\end{array}$ & 0.69 & $11^{\text {th }}$ & \\
\hline Procurement & $\begin{array}{l}\text { Assign in tender evaluation equal } \\
\text { weightage on the most } \\
\text { environmentally favourable offer as } \\
\text { same as the least cost and } \\
\text { technically feasible offer }\end{array}$ & 0.68 & $12^{\text {th }}$ & \\
\hline $\begin{array}{l}\text { Green building } \\
\text { indexing }\end{array}$ & $\begin{array}{l}\text { Introduce green building index and } \\
\text { indices along with the national green } \\
\text { specification applicable for } \\
\text { construction }\end{array}$ & 0.68 & $12^{\text {th }}$ & \\
\hline $\begin{array}{l}\text { Disaster } \\
\text { resilience }\end{array}$ & $\begin{array}{l}\text { Emphasize the use of building } \\
\text { resilient concept and mainstream } \\
\text { disaster risk reduction into } \\
\text { construction practices and structures }\end{array}$ & 0.68 & $12^{\text {th }}$ & $\begin{array}{l}\text { National Policy } \\
\text { on Disaster } \\
\text { Management, Sec } \\
\text { 25.b/27.a }\end{array}$ \\
\hline $\begin{array}{l}\text { Sustainable } \\
\text { Construction } \\
\text { Index }\end{array}$ & $\begin{array}{l}\text { Assess progress in sustainable } \\
\text { construction. The result can help a } \\
\text { nation to pinpoint areas needing } \\
\text { improvement }\end{array}$ & 0.67 & $15^{\text {th }}$ & \\
\hline
\end{tabular}




\begin{tabular}{llccc}
\hline \multicolumn{1}{c}{ Dimension } & \multicolumn{1}{c}{ Policy Profile } & RII & Rank & Policy Directives \\
\hline Bid selection & $\begin{array}{l}\text { Stipulate sustainable construction as } \\
\text { a contractor selection criterion in bid } \\
\text { documents }\end{array}$ & 0.66 & $16^{\text {th }}$ & \\
$\begin{array}{l}\text { Mapping } \\
\text { knowledge flows }\end{array}$ & $\begin{array}{l}\text { Tacit knowledge can be transferred } \\
\text { through strong ties in sparse } \\
\text { networks }\end{array}$ & 0.63 & $17^{\text {th }}$ & \\
$\begin{array}{l}\text { Valuation } \\
\text { bonus/reduction }\end{array}$ & $\begin{array}{l}\text { Assign a "valuation bonus" to a } \\
\text { sustainable building or a "valuation }\end{array}$ & 0.60 & $18^{\text {th }}$ & \\
\hline
\end{tabular}

\section{CONCLUSIONS}

This study provided a number of dimensions that can guide policy formulation in Sri Lanka. Only 3 out of 17 dimensions have been superficially earmarked within the policy framework in Sri Lanka. They have been addressed in the legislation named CIDA Act, No. 33 of 2014. The National Construction Policy and the National Policy on Disaster Management refer to environmental friendliness and building resilience respectively. In a nutshell, the Government needs to focus on policy dimensions such as traditional knowledge to sustainable bid selection, deconstruction, adaptive reuse, reduction of taxes and levies, on sustainable products and low carbon initiatives. This being said, it is for certain that there is still no fully-fledged policies present. A policy gap analysis, like this, can be beneficial in long run as this research can help present the policies that may be necessary and efficient for the entire construction industry, that will otherwise deter the implementation of sustainable construction.

\section{FURTHER RESEARCH}

It is recommended that further studies be conducted using larger samples and also a probabilistic (random) sampling approach to validate the findings of this study so that the results can be generalized. It is also imperative to see how the various factors are related. Inferential statistical methods can be employed to determine whether there exists causal relationship between the various identified variables. For example, Analytic Hierarchy Process tools would help establish consistency of human perception and judgement. Such information will provide pertinent information on how to promote sustainable construction practices in Sri Lanka.

\section{REFERENCES}

Abrahams, G. 2017. Constructing definitions of sustainable development. Smart and Sustainable Built Environment, 6(1), pp.34-47.

Ahn, Y.H., Pearce, A.R., Wang, Y. and Wang G. 2013. Drivers and barriers of sustainable design and construction: The perception of green building experience. International Journal of Sustainable Building Technology and Urban Development, 4(1), pp.35-45.

Arif, M., Egbu, C., Haleem, A., Kulonda, D., and Khalfan, M. (2009). State of green construction in India: drivers and challenges. Journal of Engineering, Design and Technology, 7(2), pp.223-234.

Athapaththu, K.I. and Karunasena, G. 2018. Framework for sustainable construction practices in Sri Lanka. Built Environment Project and Asset Management, 8(1), pp.51-63.

Bash T. and Heikines K. 2015. Barriers and drivers for sustainable building. Building Research \& Information, 39(3), pp.239-255. 
Bourdeau, L. 1999. Sustainable development and the future of construction: a comparison of visions from various countries, Building Research \& Information, 27(6), pp.354-366.

DuBose, J.R. and Pearce, A.R. 1997. The Natural Step as an assessment tool for the built environment. Proceedings Second International Conference on Buildings and the Environment, CSTB and CIB, June, pp.595-602.

Heijden, A. and Bueren, D. 2013, Sustainable Leadership, San Francisco, CA: Jossey- Bass

Hill, R. C., and Bowen, P. A., 1997. Sustainable construction: principles and a framework for attainment. Construction Management and Economics, 15(3), pp.223-239.

Johnson, J. W. and LeBreton, J. M. 2004. History and Use of Relative Importance Indices in Organizational Research. Organizational Research Methods, 7, pp.238-257.

Karunasena, G., Rathnayake, R.M.N.U. and Senarathne, D. 2016. Integrating sustainability concepts and value planning for sustainable construction. Built Environment Project and Asset Management, 6(2), pp. $125-138$.

Jian Zuo, Kunhui Ye, Martin Skitmore, Bo Xiong, Xiaolong Gan 2015 Why sustainable construction? Why not? An owner's perspective, Habitat International, pp.61-68.

Lawson, W. R. 1992. Capital energy costs of building and the recycling of building materials. Proceedings of Construction Beyond 2000, Espoo, Finland.

Lund, T. 2012. Combining qualitative and quantitative approaches: Some arguments for mixed methods research. Scandinavian Journal of Educational Research, 56(2), pp.155-165.

Majdalani, Z., Ajam M. and Mezher, T. 2006. Sustainability in the construction industry: A Lebanese case study. Construction Innovation, 6(1), pp.33-46.

Meacham, B.J., 2016. Sustainability and resiliency objectives in performance building regulations. Building Research \& Information, 44(5-6), pp.474-489.

Opoku, A. and Ahmed, V., 2013. Understanding sustainability: A view from Inta-organisational Leadership within UK construction organisations. International Journal of Architecture, Engineering and Construction, 2 (2), pp.120-130.

Plessis, C.D. 2007. A strategic framework for sustainable construction in developing countries. Construction Management and Economics, 25(1), pp.67-76.

Presley, A. and Meade, L. 2010. Benchmarking for sustainability: An application to the sustainable construction industry. Benchmarking: An International Journal, 17(3), pp.435-451.

Neuman, W.L. 2011. Social Research Methods: Qualitative and Quantitative Approaches. $7^{\text {th }}$ ed. Boston: Pearson.

Ogunbiyi, O., Goulding, J.S. and Oladapo, A. 2014. An empirical study of the impact of lean construction techniques on sustainable construction in the UK. Construction Innovation, 14(1), pp.88-107.

Roper, K.O. and Beard J.L. 2006. Justifying sustainable buildings: Championing green operations. Journal of Corporate Real Estate, 8(2), pp.91-103.

Rydin, Y., Amjad, U. and Whitaker, M. 2007. Environmentally Sustainable Construction: Knowledge and Learning in London Planning Departments. Planning Theory \& Practice, 8(3), pp.363-380.

Sfakianaki, E. 2015. Resource-efficient construction: Rethinking construction towards sustainability. World Journal of Science, Technology and Sustainable Development, 12(3), pp.233-242.

Shi, Q., Zuo, J. and Zillante G. 2012. Exploring the management of sustainable construction at the programme level: A Chinese case study. Construction Management and Economics, 30(6), pp.425-440.

Vandierendonck, A., Liefooghe, B., and Verbruggen, F., Task switching: interplay of reconfiguration and interference control. Psychological Bulletin, 136(4), pp.601, 2010.

Warnock, C. 2007. Bringing existing buildings into the sustain-ability equation. New Zealand Sustainable Building Conference SB07. CIB, Auckland.

WCED. 1987. Our common future. New York, Oxford Univ. Press.

Wyatt, D.P., Sobotka, A. and Rogalska, M. 2000. Towards a sustainable practice. Facilities, 18(1/2), pp.7682. 